\title{
Organochlorine pesticide levels in Clarias gariepinus from polluted freshwater impoundments in South Africa and associated human health risks
}

\author{
I.E.J. Barnhoorn ${ }^{\text {a,* }}$, J.C. van Dyk ${ }^{\text {b }}$, B. Genthe ${ }^{\text {c }}$, W.R. Harding ${ }^{\text {d }}$, G.M. Wagenaar ${ }^{\text {b }}$, M.S. Bornman ${ }^{\text {e }}$
}

\author{
a Department of Zoology, School of Mathematical and Natural Sciences, University of Venda, Private Bag X5050, Thohoyandou 0950, South \\ Africa ${ }^{\mathrm{b}}$ Department of Zoology, University of Johannesburg, P.O. Box 524, Auckland Park, 2006, Johannesburg, South Africa

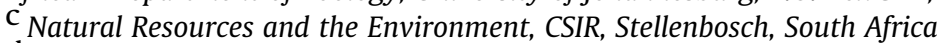 \\ d DH Environmental Consulting, PO Box 5429, Helderberg 7135, South Africa \\ e Andrology, Department of Urology, University of Pretoria, Private Bag X169, Pretoria 0001, South Africa
}

H i g h l i g h t s

- Clarias gariepinus muscle tissue bio-accumulated organochlorine pesticides.

- Predicted risk of developing cancer is higher than the recommended safe value of 1 .

- The Roodeplaat Dam risk is as a result of muscle levels of dieldrin and aldrin.

- Non-carcinogenic risks were 2 to 6 times that of the level considered to be safe.

A b s t r a c t

There are increasing concerns regarding the safe human consumption of fish from polluted, freshwater impoundments. The aim of this study was to analyse the muscle tissue of the sharptooth catfish Clarias gariepinus for selected organo-chlorine pesticides (OCPs) and to perform a human health risk assessment using a standard protocol described by the United States Environmental Protection Agency (US EPA). Fish were collected from the polluted Roodeplaat-(RDPD), Rietvlei-(RVD) and Hartbeespoort (HBPD) Dam impoundments located in the north-eastern regions of South Africa. GC-MS analyses showed levels of various OCPs in fish muscle samples from all three impoundments. For fish collected from the RDPD, $p, p^{\prime}$-DDE, endosulfan, lindane and $\beta$ and $\delta$-HCH were the most prevalent OCPs detected, while $p, p^{\prime}$-DDE and endosulfan were the most predominant in fish from the RVD. Lindane and $\beta$ - and $\delta$ $\mathrm{HCH}$ were the main OCPs detected in fish from the HBPD. Dieldrin was the only OCP detected at concentrations for which a cancer risk and a hazard index above the acceptable risk levels were estimated. This was the case for fish from both the RDPD and RVD impoundments. No toxic risk was estimated should fish from the HBPD be consumed.

Keywords:

Muscle tissue, Organo-chlorine pesticides Human health, Cancer risk, Toxic risk, Fish consumption

\section{Introduction}

Fish is a primary source of protein for many poor, self-sustaining rural communities living in the vicinity of freshwater impoundments in South Africa. However, many of these impoundments are polluted and the consumption of contaminated fish could be a primary source of human exposure to various environmental pollutants (European Food Safety Authority (EFSA), 2005; Storelli, 2008). The Roodeplaat (RDPD)-, Rietvlei (RVD)-, and Hartbeespoort

\footnotetext{
* Corresponding author. Tel.: +27 15962 8041; fax: +27 159628648. E-mail address: irene.barnhoorn@univen.ac.za (I.E.J. Barnhoorn).
}

Dam (HBPD) impoundments are located in the Gauteng- and North West provinces of South Africa respectively, and are severely polluted and classified as hyper-eutrophic ecosystems (van Ginkel, 2011). All receive effluent from various human activities including industry, mining, agriculture and wastewater treatment works.

The sharptooth catfish Clarias gariepinus is a predominant species in these systems and subsequently an important food source for local communities (personal communication from local fishermen). Although DDT is not used for vector control in the study areas, previous studies by Bornman et al. (2007) and the Department of Water Affairs (DWA) (2012) reported levels of DDT and its metabolites, DDD and DDE, as well as other organochlorine pes- 
ticides (OCPs) in muscle tissue of $C$. gariepinus from the RVD and HBPD respectively. A number of individual fish had OCP levels above the recommended limit for daily human intake as stipulated by the World Health Organisation (WHO) and US Food and Drug Administration (FDA). Studies also showed reproductive abnormalities including intersex in C. gariepinus from the RVD (Barnhoorn et al., 2004; Pieterse et al., 2010) and Oreochromis mossambicus (Peters, 1852) from the RDPD (Marchand et al., 2012).

DDT and its metabolites as well as other OCPs may pose as endocrine disruptor chemicals (EDCs) (Klotz et al., 1996; Kramer and Giesy, 1999; Kojima et al., 2004). EDCs mimic or antagonize the action of hormones within the body (Kelce et al., 1995). This can result in developmental, growth, and reproductive abnormalities (Jobling et al., 1998; Barnhoorn et al., 2009; Marchand et al., 2010). In specific regions of South Africa, approximately $500 \mathrm{~km}$ from the study sites, DDT is still used annually to eradicate the Anopheles funestus and Anopheles arabiensis malaria vectors in an effort to control the spread of the disease (Urbach, 2007). This is done in accordance with the interim recommendations of the Stockholm Convention (Bouwman, 2004). Unfortunately, these vector control measures inevitably result in the contamination of the surrounding environment (and possibly other parts of the country as far as the Gauteng Province through aerial transport). Illegal use of banned pesticides like DDT and local runoff from agricultural and industrial activities should also be considered as possible contamination sources (Bornman et al., 2007; Barnhoorn et al., 2010).

As both DDT and its metabolites persist in the environment (Agency for Toxic Substances and Disease Registry (ATSDR), 2002a), humans consuming potentially contaminated fish will typically be exposed to a mixture of these chemicals, collectively referred to as the total DDT ( $\Sigma$ DDT). Fish consumption advisory guidelines are therefore based on the $\Sigma$ DDT levels detected in fish muscle tissue (ATSDR, 2002a). In addition to DDT, other OCPs have also been detected in the mesenteric fat of fish from the RVD, including aldrin and lindane (Bornman et al., 2007), while dieldrin, $\alpha$-lindane and $\beta$-lindane concentrations were found in muscle tissues of fish from the HBPD (DWA, 2012).

A need to assess the safety of human consumption of freshwater fish, specifically related to chemical contamination, has been recognised across the globe and various studies have focussed specifically on OCPs and the associated human health risks (Chan et al., 1999; Jiang et al., 2005; Zhao et al., 2011; Wang et al., 2013). This need was highlighted for South African freshwater systems by Du Preez et al. (2003), who proposed a "Methodology for the assessment of human health risks associated with the consumption of chemically-contaminated freshwater fish in South Africa".

However, currently no information is available on the human health risks associated with the consumption of contaminated fish for most of the freshwater impoundments in South Africa, and more specifically the RDPD, RVD and HBPD impoundments. The aim of this study was therefore to analyse the muscle tissue of $C$. gariepinus from these impoundments for selected OCPs and to perform a human health risk assessment using a standard protocol described by the United States Environmental Protection Agency (US EPA) (US EPA, 1991).

\section{Materials and methods}

\subsection{Fish and tissue sampling}

Twenty C. gariepinus were collected from each of the three impoundments during the summer months of 2007. Fish were collected using gill nets and seine nets: [RDPD (50\% male/50\% female, mean body mass $3318 \mathrm{~g} \pm 1193 \mathrm{~g}$ ); RVD (45\% male/55\% female, mean body mass $4145 \mathrm{~g} \pm 1748 \mathrm{~g}$ ); HBPD ( $50 \%$ male/50\% female, mean body mass $2650 \mathrm{~g} \pm 1047.55 \mathrm{~g})$ ]. Fish were sacrificed by severing the spinal cord anterior to the dorsal fin. A skeletal muscle tissue sample of approximately $20 \mathrm{~g}$ (wet weight) was collected per fish and stored in aluminium foil at $-20^{\circ} \mathrm{C}$ until further laboratory processing and analyses by an ISO-17025 accredited laboratory.

\subsection{Chemical analyses}

Tissue samples were specifically analysed for selected OCPs including the six 1,1,1-trichloro-2,2-bis(p-chlorophenyl)ethane (DDT) isomers (o, $p^{\prime}$ - and $p, p^{\prime}$-DDT, - 1,1-dihloro-2,2-bis(p-chlorophenyl)ethane (DDD) and - 1,1-dihloro-2,2-bis(p-chlorophenyl)ethylene (DDE), aldrin, dieldrin, endrin, endrin aldehyde, endrin ketone, endosulfan I, endosulfan II, heptachlor, heptachlor epoxide, alpha $(\alpha)$-, beta $(\beta)-$, gamma $(\gamma)$ - (lindane), delta $(\delta)$ isomers of hexachlorocyclohexane $(\mathrm{HCH})$ and methoxychlor.

The samples were analysed using a gas chromatography mass spectrometry (GC-MS) system with a MSD Chemstation E.01.00.232 software data processing package. The procedure was based on the methodology described by Bordet et al. (2002). In summary: Organochlorines were extracted from muscle samples (wet basis) with a mixture of acetonitrile-dichloromethane. The average lipid content of $C$. gariepinus, $1.15 \% \pm 0.24 \%$, was taken form Osibona et al. (2006). After centrifugation the supernatant were reduced and cleaned -up on a C18 cartridge, followed by a further Florisil cartridge. The pesticide ranges were eluted using two different elution solutions. Extraction efficiency was confirmed by adding an internal standard, decachlorobiphenyl, at the onset of the extraction procedure. A percentage recovery of the internal standard per sample of $>85 \%$ was used as an indicator. Quantification of positive analytes was accomplished via a matrix assisted calibration curve.

\subsection{Human health risk assessment}

The human health risk assessment was done according to the methodology described by the US EPA (1991). The exposure parameters used were stipulated as follows: An average bodyweight of $70 \mathrm{~kg}$; a life expectancy of 70 years; exposure duration of 30 years with a weekly fish muscle consumption averaged at $350 \mathrm{~g}$.

\subsubsection{Average daily dose (ADD) and the lifetime average daily dose} (LADD)

To evaluate the risk of contracting cancer and chronic non-cancerous toxic health effects from oral exposure, the average daily dose (ADD) and the lifetime average daily dose (LADD) were used (US EPA, 1991). The ADD or exposure concentration ( $\mathrm{mg} \mathrm{kg} \mathrm{d}^{-1}$ ) expected to be ingested during the period of exposure was calculated as follows: $\mathrm{ADD}=[\mathrm{C}(\mathrm{m}) \times \mathrm{IR} \times \mathrm{ED} \times \mathrm{EF}] /(\mathrm{BW})$ where $\mathrm{C}(\mathrm{m})=$ contaminant concentration $(\mathrm{mg}) ; \quad \mathrm{IR}=$ ingestion rate $\left(\mathrm{kg} \mathrm{d}^{-1}\right) ; \mathrm{ED}=$ exposure duration (years); $E F=$ exposure frequency (days per year); BW = body weight $(\mathrm{kg})$. The LADD or concentration that would yield an equivalent exposure if exposure continued for the entire lifetime was calculated as follows: LADD = ADD/ED.

\subsubsection{Carcinogenic risk}

Cancer risk estimates represent the risk of developing cancer over and above the background cancer rate. To evaluate the carcinogenic risks from exposures that last less than a lifetime, the ADD was adjusted to LADD or cancer risks were calculated using the formula: Risk $=\mathrm{e}^{-}$(oral slope factor $*$ LADD $)$. 


\subsubsection{Hazard Index or toxic risk}

For agents that cause non-cancerous toxic effects, a Hazard Index (HI) was calculated. The HI compares the expected exposure to a chemical to an exposure that is assumed not to be associated with toxic effects. For oral exposures, the ADD is compared to a RfD (available online at http://www.epa.gov/IRIS/) and was calculated as: $\mathrm{HI}=\mathrm{ADD} / \mathrm{RfD}$. The RfD is a conservative estimate of non-cancer toxic hazards with differences in sensitivity to toxic effects within and between species, and differences in toxic effects between chronic and sub-chronic exposures taken into account. The HI is expressed as milligrams of contaminant per $\mathrm{kg}$ of body weight per day.

\section{Results}

\subsection{Levels of OCPs detected in the muscle tissue}

The analyses showed levels of various OCPs in fish muscle samples from all three impoundments. These findings are presented per site in Tables 1-3 respectively. OCPs which were detected in more than $15 \%(n=3)$ of fish from RDPD included $p, p^{\prime}$-DDE, lindane $(\gamma-\mathrm{HCH})$, endosulfan, endrin and dieldrin; in fish from RVD, $p, p^{\prime}-$ DDE, $p, p^{\prime}$-DDT, heptachlor, dieldrin, endosulfan II and $\delta$-HCH; and in fish from HBPD, $\beta$-HCH, $\delta$ - $\mathrm{HCH}$ and $p, p^{\prime}$-DDE.

The most prevalent OCPs detected $(n=\geqslant 4)$ in fish from RDPD were $p, p^{\prime}$-DDE, dieldrin, endosulfan and lindane. The $p, p^{\prime}$-DDE concentrations ranged between 77.7 and $350.8 \mu \mathrm{g} \mathrm{kg}^{-1}$, dieldrin concentrations ranged between 128.5 and $314.5 \mu \mathrm{g} \mathrm{kg}^{-1}$, endosulfan between 141.4 and $516.2 \mu \mathrm{g} \mathrm{kg}^{-1}$, and lindane between 108.4 and $514.8 \mu \mathrm{g} \mathrm{kg}^{-1}$. Levels of $p, p^{\prime}$-DDD, $p, p^{\prime}$-DDT, $o, p^{\prime}$-DDT, heptachlor and methoxychlor were detected only in one of the sampled fish. Aldrin, endrin aldehyde, $\alpha-\mathrm{HCH}$, and $\delta$ - $\mathrm{HCH}$ each occurred in only any two samples. The highest mean OCP concentrations detected within the sample group were associated with dieldrin, endosulfan and lindane ( $\left.>200 \mu \mathrm{g} \mathrm{kg}^{-1}\right)$.

Fish from the RVD also had detectable levels of DDT and its metabolites DDD and DDE, as well as detectable levels of dieldrin, endosulfan I, endosulfan II, endrin, heptachlor, and $\delta$-HCH (Table 2).
Most prevalent, was $p, p^{\prime}-\mathrm{DDE}(n=10)$ and endosulfan II $(n=9)$. Only $p, p^{\prime}$-DDE had a mean concentration above $200 \mu \mathrm{g} \mathrm{kg}^{-1}$ with a range of 72.4 to $424.6 \mu \mathrm{g} \mathrm{kg}^{-1}$. The concentrations of endosulfan II ranged between 57.2 and $129.5 \mu \mathrm{g} \mathrm{kg}^{-1}$.

Only three OCPs were detected in fish muscle samples from the HBPD namely $p, p^{\prime}$-DDE, $\beta$ - $\mathrm{HCH}$ and $\delta$ - $\mathrm{HCH}$ (Table 3 ). $\beta$ - $\mathrm{HCH}$ was detected in $60 \%(n=12)$ of fish, ranging between 60.7 and $111.5 \mu \mathrm{g} \mathrm{kg}^{-1}$ and $\delta-\mathrm{HCH}$ in $85 \%(n=17)$ of fish ranging between 52.4 and $95.9 \mu \mathrm{g} \mathrm{kg}^{-1}$.

\subsection{Human health risk assessment}

Oral ingestion of fish was assumed making use of default ingestion values from the US EPA (1991). Only compounds which were detected in three or more individual fish per site were used for the calculations (Table 4 ) with the exception of dieldrin for $\operatorname{RVD}(n=2)$, which was calculated to compare to the high concentrations of dieldrin detected in fish from RDPD. The ADD and LADD were calculated making use of the assumptions of body weight, number and size of meals, and exposure duration as described in Section 2.2, with the results shown in Table 4.

\subsubsection{Cancer risk}

The risk assessment showed a potential risk of developing cancer should contaminated fish from RDPD be consumed. The total cancer risk calculated was highest for the RDPD and the lowest for the HBPD (Fig. 1). The total risk of developing cancer with the assumed exposures ranged between a high of 1 in 1000 (1.0 E-3) at the RDPD to a low of 5 in 100000 (5.0 E-5) at the HBPD (Fig. 1). The risk calculated for fish consumption for the RDPD was mainly associated with the dieldrin and $\gamma$-lindane levels detected. The total risk for RVD was lower compared to RDPD and was associated with a number of OCPs including $p, p^{\prime}$-DDE, $p, p^{\prime}$-DDT, dieldrin, heptachlor and $\delta$ - $\mathrm{HCH}$, all with a cancer risk higher than the acceptable risk of 0.00001 . The cancer risk calculated for fish from the HBPD was associated with $p, p^{\prime}$-DDE, $\beta$ and $\delta$ - $\mathrm{HCH}$ only.

Table 1

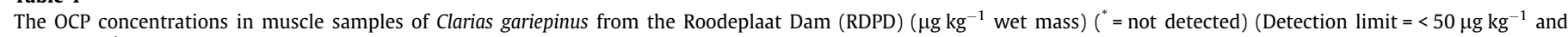
$<75 \mu \mathrm{g} \mathrm{kg}^{-1}$ for lindane ( $\gamma$, endosulfan and $p, p^{\prime}$-DDT).

\begin{tabular}{|c|c|c|c|c|c|c|c|c|c|c|c|c|c|c|c|}
\hline Fish no & $\begin{array}{l}p, p^{\prime}- \\
\text { DDD }\end{array}$ & $\begin{array}{l}p, p^{\prime}- \\
\text { DDE }\end{array}$ & $\begin{array}{l}p, p^{\prime}- \\
\text { DDT }\end{array}$ & $\begin{array}{l}o, p^{\prime}- \\
\text { DDT }\end{array}$ & $\Sigma D D T$ & Aldrin & Dieldrin & $\begin{array}{l}\text { Endosulfan } \\
\text { I }\end{array}$ & $\begin{array}{l}\text { Endrin } \\
\text { aldehyde }\end{array}$ & Endrin & Heptachlor & $\alpha-\mathrm{HCH}$ & Lindane & $\begin{array}{l}\delta- \\
\mathrm{HCH}\end{array}$ & Methoxychlor \\
\hline 1 & $*$ & $*$ & $*$ & * & * & $*$ & * & * & * & * & $*$ & * & 111.4 & 145.8 & * \\
\hline 2 & * & 107.6 & $*$ & $*$ & 107.6 & $*$ & 297.6 & 141.4 & 197.4 & * & $*$ & * & $*$ & * & $*$ \\
\hline 3 & $*$ & * & 168.4 & $*$ & 168.4 & $*$ & $*$ & $*$ & $*$ & * & $*$ & * & 108.4 & $*$ & $*$ \\
\hline 4 & $*$ & 350.8 & * & $*$ & 350.8 & $*$ & $*$ & $*$ & $*$ & $*$ & $*$ & $*$ & 162.8 & $*$ & $*$ \\
\hline 5 & * & 77.7 & $*$ & $*$ & 77.7 & $*$ & * & $*$ & $*$ & $*$ & $*$ & * & * & $*$ & * \\
\hline 6 & $*$ & $*$ & $*$ & $*$ & $*$ & $*$ & * & $*$ & $*$ & $*$ & * & $*$ & 135.9 & * & * \\
\hline 7 & $*$ & 112.8 & $*$ & $*$ & 112.8 & $*$ & $*$ & 516.2 & $*$ & $*$ & $*$ & $*$ & $*$ & 120.1 & $*$ \\
\hline 8 & $*$ & 112.3 & $*$ & $*$ & 112.3 & 91.2 & * & $*$ & $*$ & $*$ & $*$ & * & 118.8 & * & $*$ \\
\hline 9 & $*$ & 89 & $*$ & $*$ & 89 & $*$ & 218.6 & * & 123.9 & 133.2 & $*$ & * & 256 & $*$ & $*$ \\
\hline 10 & 113.1 & $*$ & $*$ & 113.4 & 226.5 & 81.7 & $*$ & $*$ & $*$ & 126 & 288.6 & * & 166.5 & $*$ & 106 \\
\hline 11 & $*$ & 112.6 & $*$ & * & 112.6 & $*$ & $*$ & $*$ & $*$ & $*$ & $*$ & $*$ & $*$ & $*$ & $*$ \\
\hline 12 & $*$ & $*$ & $*$ & $*$ & $*$ & * & 128.5 & 206.2 & * & * & $*$ & * & 157.4 & * & * \\
\hline 13 & $*$ & $*$ & $*$ & * & $*$ & * & 314.5 & 225.5 & * & 150.7 & * & * & 514.8 & * & * \\
\hline 14 & $*$ & $*$ & $*$ & $*$ & $*$ & $*$ & $*$ & $*$ & $*$ & $*$ & $*$ & $*$ & $*$ & $*$ & $*$ \\
\hline 15 & $*$ & $*$ & $*$ & * & $*$ & $*$ & * & 175 & * & $*$ & * & 201.6 & 117.8 & * & $*$ \\
\hline 16 & $*$ & $*$ & $*$ & $*$ & $*$ & $*$ & $*$ & 325.1 & * & * & * & 375.9 & 119.7 & * & * \\
\hline 17 & $*$ & $*$ & $*$ & $*$ & $*$ & $*$ & $*$ & 216 & $*$ & $*$ & $*$ & $*$ & $*$ & $*$ & $*$ \\
\hline 18 & $*$ & $*$ & $*$ & $*$ & * & $*$ & $*$ & $*$ & $*$ & $*$ & $*$ & * & $*$ & $*$ & $*$ \\
\hline 19 & $*$ & $*$ & * & $*$ & * & * & * & 152.4 & * & * & * & * & * & * & * \\
\hline 20 & $*$ & $*$ & $*$ & * & $*$ & $*$ & * & $*$ & * & * & $*$ & $*$ & $*$ & * & $*$ \\
\hline Mean & $\mathrm{n} / \mathrm{a}$ & 137.5 & $\mathrm{n} / \mathrm{a}$ & $\mathrm{n} / \mathrm{a}$ & 150.9 & 86.45 & 239.8 & 244.7 & 160.7 & 136.6 & $\mathrm{n} / \mathrm{a}$ & 288.75 & 179.0 & 133.0 & $\mathrm{n} / \mathrm{a}$ \\
\hline$\pm \mathrm{SD}$ & $\mathrm{n} / \mathrm{a}$ & 95.0 & $\mathrm{n} / \mathrm{a}$ & $\mathrm{n} / \mathrm{a}$ & 87.6 & 6.7 & 85.2 & 123.6 & 52.0 & 12.7 & $\mathrm{n} / \mathrm{a}$ & 123.2 & 119.1 & 18.2 & $\mathrm{n} / \mathrm{a}$ \\
\hline Median & $\mathrm{n} / \mathrm{a}$ & 112.3 & $\mathrm{n} / \mathrm{a}$ & $\mathrm{n} / \mathrm{a}$ & 112.6 & 86.5 & 258.1 & 211.1 & 160.7 & 133.2 & $\mathrm{n} / \mathrm{a}$ & 288.8 & 135.9 & 133.0 & $\mathrm{n} / \mathrm{a}$ \\
\hline
\end{tabular}


Table 2

The OCP concentrations in muscle samples of Clarias gariepinus from Rietvlei Dam (RVD) $\left(\mu \mathrm{kg}^{-1}\right.$ wet mass $)\left({ }^{*}=\right.$ not detected $)\left(\right.$ Detection limit $\left.=<50 \mu \mathrm{kg}{ }^{-1}\right)$.

\begin{tabular}{|c|c|c|c|c|c|c|c|c|c|c|}
\hline Fish no & $p, p^{\prime}-\mathrm{DDD}$ & $p, p^{\prime}-\mathrm{DDE}$ & $p, p^{\prime}$-DDT & $\Sigma$ DDT & Dieldrin & Endosulfan I & Endosulfan II & Endrin & Heptachlor & $\delta$ - $\mathrm{HCH}$ \\
\hline 1 & $*$ & $*$ & $*$ & * & * & * & $*$ & $*$ & $*$ & $*$ \\
\hline 2 & $*$ & * & $*$ & * & 52.0 & * & 118 & $*$ & 75.1 & * \\
\hline 3 & $*$ & 99.4 & $*$ & 99.4 & $*$ & $*$ & 73.8 & * & 65.9 & $*$ \\
\hline 4 & 66.5 & 247.2 & 85.8 & 399.5 & $*$ & $*$ & 99.0 & $*$ & $*$ & $*$ \\
\hline 5 & $*$ & 76.5 & $*$ & 76.5 & * & * & 129.5 & $*$ & * & 51.8 \\
\hline 6 & 188.1 & 300.5 & 275.8 & 764.4 & * & $*$ & $*$ & $*$ & $*$ & $*$ \\
\hline 7 & $*$ & 187.7 & $*$ & 187.7 & $*$ & $*$ & 83.7 & $*$ & $*$ & $*$ \\
\hline 8 & $*$ & 82.9 & $*$ & 82.9 & $*$ & $*$ & $*$ & $*$ & * & * \\
\hline 9 & $*$ & $*$ & $*$ & $*$ & * & * & $*$ & $*$ & 58.6 & $*$ \\
\hline 10 & $*$ & 424.6 & 176.1 & 600.7 & $*$ & $*$ & $*$ & * & 61.2 & $*$ \\
\hline 11 & $*$ & 402.8 & 189.1 & 591.9 & * & $*$ & * & $*$ & $*$ & $*$ \\
\hline 12 & $*$ & 72.4 & $*$ & 72.4 & * & 57.6 & * & $*$ & $*$ & * \\
\hline 13 & $*$ & $*$ & $*$ & $*$ & $*$ & $*$ & $*$ & $*$ & $*$ & 50.7 \\
\hline 14 & $*$ & $*$ & $*$ & $*$ & $*$ & $*$ & $*$ & $*$ & $*$ & 62.8 \\
\hline 15 & $*$ & 223.4 & 263.4 & 486.8 & $*$ & * & 60.1 & $*$ & $*$ & $*$ \\
\hline 16 & $*$ & * & $*$ & $*$ & $*$ & $*$ & $*$ & * & * & * \\
\hline 17 & $*$ & $*$ & $*$ & $*$ & $*$ & * & 57.2 & * & * & * \\
\hline 18 & $*$ & $*$ & $*$ & $*$ & $*$ & $*$ & $*$ & $*$ & $*$ & $*$ \\
\hline 19 & * & * & $*$ & * & $*$ & * & 93.1 & 97.0 & $*$ & * \\
\hline 20 & $*$ & * & $*$ & * & 102.9 & * & 61.9 & $*$ & 155.3 & * \\
\hline Mean & 127 & 212 & 198 & 336 & 77 & $\mathrm{n} / \mathrm{a}$ & 86 & $\mathrm{n} / \mathrm{a}$ & 83 & 55 \\
\hline$\pm \mathrm{SD}$ & 86 & 133 & 77 & 263 & 36 & $\mathrm{n} / \mathrm{a}$ & 26 & $\mathrm{n} / \mathrm{a}$ & 41 & 7 \\
\hline Median & 127 & 206 & 189 & 294 & 77 & $\mathrm{n} / \mathrm{a}$ & 84 & $\mathrm{n} / \mathrm{a}$ & 66 & 52 \\
\hline
\end{tabular}

Table 3

The OCP concentrations in muscle samples of Clarias gariepinus from Hartbeespoort Dam (HBPD) ( $\mu \mathrm{g} \mathrm{kg}^{-1}$ wet mass) $\left(^{*}=\right.$ not detected) (Detection limit $=<50 \mu \mathrm{g} \mathrm{kg}^{-1}$ ).

\begin{tabular}{clll}
\hline Fish no & $p, p^{\prime}$-DDE & $\beta$-HCH & $\delta$-HCH \\
\hline 1 & $*$ & $*$ & $*$ \\
2 & $*$ & $*$ & 65.4 \\
3 & 101.9 & 75.6 & $*$ \\
4 & $*$ & $*$ & $*$ \\
5 & 124.6 & 111.5 & 95.9 \\
6 & $*$ & $*$ & 52.4 \\
7 & 161 & 68.9 & 61 \\
8 & $*$ & $*$ & 56.1 \\
9 & $*$ & 102.9 & 71.4 \\
10 & $*$ & 84.5 & 65.4 \\
11 & $*$ & $*$ & 68.8 \\
12 & $*$ & 62.6 & 70.3 \\
13 & $*$ & 61.8 & 60 \\
14 & $*$ & $*$ & 60.1 \\
15 & 135.2 & 101 & 127 \\
16 & $*$ & 79.6 & 62.1 \\
17 & $*$ & 60.7 & 75.8 \\
18 & $*$ & $*$ & 58.6 \\
19 & $*$ & 70.2 & 76.8 \\
20 & $*$ & 73.4 & 72 \\
Mean & 131 & 79 & 71 \\
\pm SD & 25 & 17 & 18 \\
Median & 130 & 75 & 65 \\
\hline & & &
\end{tabular}

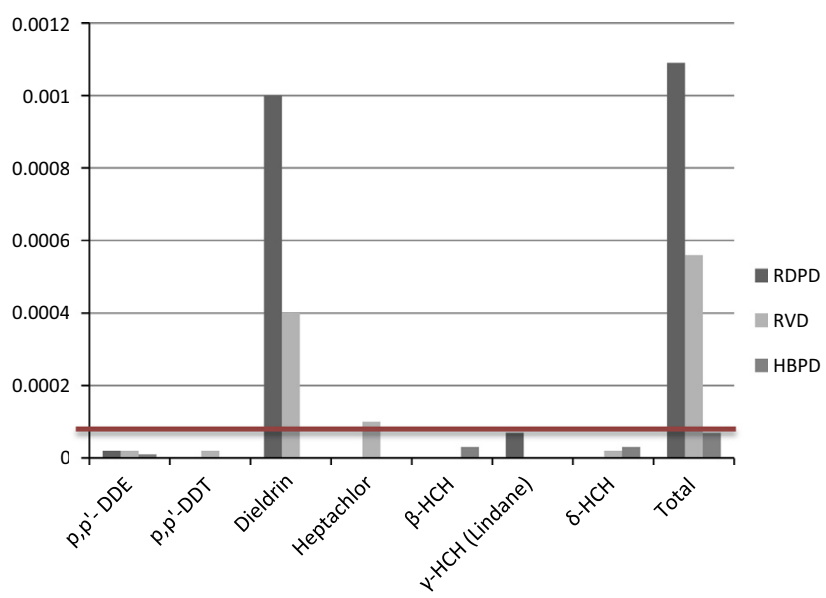

Fig. 1. Risk of developing cancer as a result of fish ingestion from the three impoundments. The red line indicates the unacceptable risk of 1 in 10000 . (For interpretation of the references to colour in this figure legend, the reader is referred to the web version of this article.)

Table 4

Mean concentrations of OCPs selected for the human health risk assessment and the average and lifetime daily doses (ADD \& LADD) calculated.

\begin{tabular}{|c|c|c|c|c|c|c|c|c|c|c|}
\hline & & $p, p^{\prime}-\mathrm{DDE}$ & $p, p^{\prime}-\mathrm{DDT}$ & Dieldrin & Endosulfan & Endrin & Heptachlor & $\beta$ - $\mathrm{HCH}$ & Lindane & $\delta$ - $\mathrm{HCH}$ \\
\hline \multirow[t]{3}{*}{ RDPD } & Measured $[\mathrm{OCP}]$ in muscle $\left(\mathrm{mg} \mathrm{kg}^{-1}\right)$ & 0.137500 & - & 0.239800 & 0.244700 & 0.136600 & - & - & 0.179000 & - \\
\hline & $\mathrm{ADD}\left(\mathrm{mg} \mathrm{kg} \mathrm{d}^{-1}\right)$ & 0.000096 & - & 0.000164 & 0.000168 & 0.000096 & - & - & 0.000123 & - \\
\hline & $\mathrm{LADD}\left(\mathrm{mg} \mathrm{kg} \mathrm{d}^{-1}\right)$ & 0.000041 & - & 0.00007 & 0.000072 & 0.000041 & - & - & 0.000053 & - \\
\hline \multirow[t]{3}{*}{ RVD } & Measured $[\mathrm{OCP}]$ in muscle $\left(\mathrm{mg} \mathrm{kg}^{-1}\right)$ & 0.212000 & 0.198000 & 0.077000 & 0.086000 & - & 0.083000 & - & - & 0.055000 \\
\hline & $\mathrm{ADD}\left(\mathrm{mg} \mathrm{kg} \mathrm{d}^{-1}\right)$ & 0.000137 & 0.00013 & 0.000051 & 0.000058 & - & 0.000045 & - & - & 0.000034 \\
\hline & $\operatorname{LADD}\left(\mathrm{mg} \mathrm{kg} \mathrm{d}^{-1}\right)$ & 0.000059 & 0.000056 & 0.000022 & 0.000025 & - & 0.000019 & - & - & 0.000015 \\
\hline \multirow[t]{3}{*}{ HBPD } & Measured $[\mathrm{OCP}]$ in muscle $\left(\mathrm{mg} \mathrm{kg}^{-1}\right)$ & 0.131000 & - & - & - & - & - & 0.079000 & - & 0.071000 \\
\hline & $\mathrm{ADD}\left(\mathrm{mg} \mathrm{kg} \mathrm{d}^{-1}\right)$ & 0.000089 & & - & - & - & - & 0.000055 & - & 0.000048 \\
\hline & $\operatorname{LADD}\left(\mathrm{mg} \mathrm{kg} \mathrm{d}^{-1}\right)$ & 0.000038 & - & - & - & - & - & 0.000023 & - & 0.00002 \\
\hline
\end{tabular}




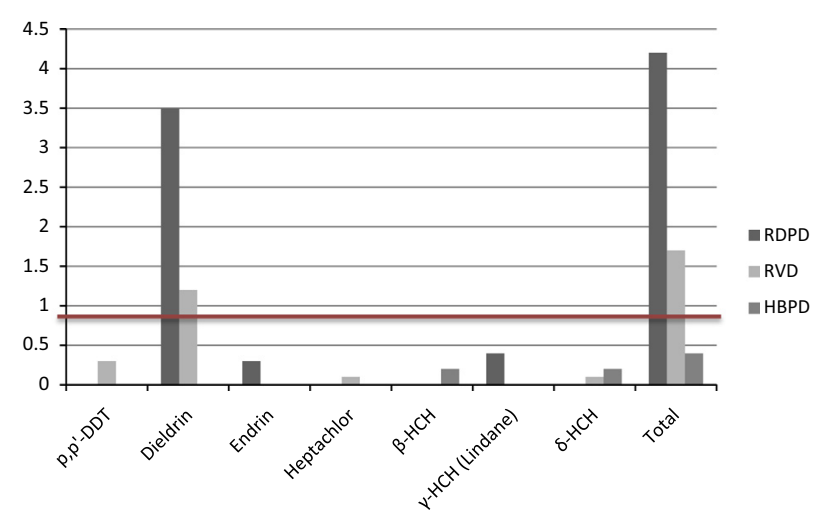

Fig. 2. Toxic risks as a result of fish ingestion expressed as a hazard index. The red line indicates the acceptable risk hazard index of 1.0. (For interpretation of the references to colour in this figure legend, the reader is referred to the web version of this article.)

\subsubsection{Hazard Index or toxic risk}

The HI was higher for the RDPD compared to the RVD. The toxic risk for fish consumption of the RDPD was mainly associated with dieldrin, endrin and $\gamma$-lindane with only dieldrin concentrations above the acceptable risk hazard index of 1.0. The toxic risk for fish from the RVD was associated with $p, p^{\prime}$-DDT, dieldrin, heptachlor and $\delta$ - $\mathrm{HCH}$ with only the $\mathrm{HI}$ for dieldrin (1.2) above the acceptable risk. No toxic risk was found should fish from the HBPD be consumed (Fig. 2).

\section{Discussion and conclusion}

The chemical analyses showed levels of various OCPs in the muscle tissue of $C$. gariepinus collected from all three impoundments. Of the different OCPs detected, $p, p^{\prime}$-DDE and endosulfan was most prevalent in the fish from the RDPD and RVD, while lindane and $\beta$ - and $\delta$-HCH was most prevalent at RDPD and HBPD respectively. Comparing the levels between impoundments, $p, p^{\prime}$ DDE concentrations were higher in RVD compared to RDPD while endosulfan levels were higher in fish from RDPD compared to RVD. Considering all the mean OCP concentrations calculated for fish from the RDPD, dieldrin, $\alpha-\mathrm{HCH}$ and endosulfan had the highest concentrations ( $>200 \mu \mathrm{g} \mathrm{kg}^{-1}$ ). Only $p, p^{\prime}$-DDE levels exceeded $200 \mu \mathrm{g} \mathrm{kg}^{-1}$ in fish from RVD. None of the mean concentrations of the OCPs detected in fish from the HBPD exceeded $200 \mu \mathrm{g} \mathrm{kg}^{-1}$.

With the exception of endosulfan, a similar combination of the most prevalent OCPs detected per impoundment i.e. mainly DDTs and/or dieldrin and/or HCHs, were found in related studies on different fish species in China (Wang et al., 2013), the Baltic Sea (Szlinder-Richert et al., 2008), Turkey (Kalyoncu et al., 2009), Greece (Christoforidis et al., 2008) and the USA (Johnson and Friese, 2013) respectively. Environmental contamination of these chemicals seems to be a global problem. The DDT residues in the muscle tissue of $C$. gariepinus from all the impoundments were unexpected as these systems are not located in close proximity to settlements where DDT is still used for vector control. Bouwman et al. (2008) suggested atmospheric deposition as a potential route of DDT contamination of aquatic ecosystems. In addition, surface runoff as a result off the possible illegal use of the pesticides in surrounding areas could also be possible sources of contamination (Bornman et al., 2007). Among the DDTs detected, $p, p^{\prime}$-DDE was the most prevalent in all the impoundments and also had the highest mean tissue concentrations. However, none of the DDT concentrations detected for any of the fish samples were above the level recommended for daily intake according to the FDA and EPA guidelines (ATSDR, 2002a). Only fish from RVD had levels of all three metabolites and thus the $\mathrm{EDDT}$ concentration was the highest for fish from this impoundments.

Apart from a potential cancer risk following DDT exposure, studies have also shown a risk of developing type 2 diabetes mellitus (Cox et al., 2007; Rignell-Hydbom et al., 2007), altered thyroid hormone levels (Alvarez-Pedrerol et al., 2008), affected immune responses in humans (Cooper et al., 2004) and in utero exposure and delayed neuro-development (Eskenazi et al., 2006). There is also a greater risk of contracting asthma (Sunyer et al., 2005), a higher chance of contracting breast cancer, especially if the exposure takes place before the age of 14 years (Cohn et al., 2007), and a risk of both seminomatous and non-seminomatous testicular carcinoma (McGlynn et al., 2008).

Endosulfan is a broad spectrum insecticide and acaricide which is widely used by many subsistence farmers in African countries (Darko et al., 2008). Endosulfan is also listed as an EDC (Park et al., 2001). Many studies have found that endosulfan has the potential to disrupt hormones and be reproductively and developmentally toxic, especially amongst males (Sang and Petrovic, 1999; ATSDR 2000). As there are no guidelines available concerning safe levels in fish tissue for human consumption, a cancer risk assessment and HI calculation could not be done.

Of the $\mathrm{HCH}$ isomers detected in fish from the three impoundments, lindane is the better known, as it is an effective pesticide used worldwide (ATSDR, 2005). The prevalence of $\gamma-\mathrm{HCH}$ (lindane) was the highest compared to the other isomers at the RDPD. Lindane is known to cause neurological, immunological, reproductive and cancerogenic effects. It is also an EDC causing hormonal imbalances in human males (Sauviat and Pages, 2002; ATSDR, 2005).

Dieldrin was the only OCP detected at concentrations that resulted in a cancer risk and $\mathrm{HI}$ above the acceptable risk levels. This was the case for both the RDPD and RVD impoundments. Dieldrin is mainly categorised as a chemical with carcinogenic potential by the EPA (Jorgenson, 2001). Studies in animals have also shown that dieldrin may result in impaired spermatozoa (ATSDR, 2002b). Dieldrin is commercially produced as an insecticide but is also a breakdown product of aldrin. The dieldrin concentrations in fish from RDPD were higher compared to the aldrin concentrations detected. The high dieldrin levels in fish from the RDPD were considered to be six times that of the "safe" level for a life time exposure. This highlights the possibility of adverse health effects in humans should fish be consumed over a long-term period (considering the stipulated population parameters in Section 2.3).

The results showed that should one consume fish from the RVD there is a 5 in 10000 chance of developing cancer while there is a 1 in 1000 chance of developing cancer should one consume fish from the RDPD. This is considerably higher than the recommended risk value (US EPA, 2011) of 1 in 100000 as an "acceptable risk". However, it is unlikely that individuals will be exposed to fish with similar, high concentrations of the OCPs over a 30 year period unless they are regular fisherman residing in the same area throughout their life-time and consuming at least $350 \mathrm{~g}$ of contaminated fish per week. Also, dieldrin was the only OCP that had a HI above the acceptable risk at both the RDPD and RVD impoundments.

In view of the findings of this study, it is important to keep the predicted risks calculated in perspective. According to the South African National Cancer Association, the general background cancer risk is 0.25 or 1 in 4 (Albrecht, 2006). The US EPA generally considers risks below 1 in a 100000 (1e-5) to be acceptable and above 1 in 10000 as unacceptable. If, for example, the calculated risk is 1 in 1000000 (or 1e-6), it suggests that a person would have a onein-a-million chance of getting cancer as a result of the specified chemical exposure, in addition to her/his chance of developing cancer from other causes. As a result of the large uncertainties associated with all risk estimates, it should always be interpreted as general indicators, rather than precise estimates (US EPA, 
1991). Therefore, further studies are needed to determine the exact frequency of fish consumption of local and recreational fishermen to provide a better indication of the certainty of the risks identified. The effect that various cooking methods will have on the bio-accumulated levels of OCPs in fish muscle tissue should also be considered.

Of most concern was the fact that some of the OCPs detected are banned substances in South Africa. Although DDT is still used for vector control in the north-eastern parts of the country, these areas are located $\pm 500 \mathrm{~km}$ away from the study area, raising concerns about the possible sources of the pollution in the study area. Furthermore, the three impoundments are all located in highly populated parts of SA, thus more people are likely to catch fish from these systems, exposing themselves to potentially contaminated fish.

\section{Acknowledgements}

The authors would like to thank the Water Research Commission of South Africa, the Universities of Pretoria and Johannesburg, National Research Foundation and DH Environmental Consulting for funding this project. Furthermore, we would also like to thank Dr. M.J. Cochrane and Mr. J. Koekemoer for the assistance with the fieldwork.

\section{References}

Albrecht, C., 2006. Overview of the South African Cancer Research Environment as a Basis for Discussions Concerning the Activation of CARISA (Cancer Research Initiative of South Africa) Report of the South African Cancer Association. <http://www.sahealthinfo.org/cancer/overviewdocument.pdf>.

Alvarez-Pedrerol, M., Ribas-Fito, N., Torrent, M., Carrizo, D., Grimalt, J.O., Sunyer, J., 2008. Effects of PCBs, p, p'-DDT, p, $\mathrm{p}^{\prime}$-DDE, HCB and $\beta$-HCH on thyroid function in preschool children. Occup. Environ. Med. 65, 452-457.

ATSDR, 2000. Toxicological Profile for Endosulfan. Atlanta, GA: U.S. Department of Health and Human Services, Public Health Service, and online at http:// www.atsdr.cdc.gov/ToxProfiles/tp41.pdf.

ATSDR, 2002a. Toxicological Profile for DDT, DDE, DDD. US Department of Health and Human Services, Public Health Service, Atlanta, GA. http:// www.atsdr.cdc.gov/toxprofiles/tp35-p.pdf.

ATSDR, 2002b. Public Health Statement Aldrin and Dieldrin. CAS\#: Aldrin 309-00-2 Dieldrin 60-57-1. Atlanta, GA: U.S. Department of Health and Human Services, Public Health Service. http://www.atsdr.cdc.gov/toxprofiles/tp1-c1-b.pdf.

ATSDR, 2005. Toxicological Profile for Hexachlorocyclohexane. Atlanta, GA: U.S. Department of Health and Human Services, Public Health Service. http:// www.atsdr.cdc.gov/toxprofiles/tp43.pdf.

Barnhoorn, I.E.J., Bornman, M.S., Pieterse, G.M., van Vuren, J.H.J., 2004. Histological evidence of intersex in feral sharptooth catfish (Clarias gariepinus) from an estrogen-polluted water source in Gauteng, South Africa. Environ. Toxicol. 19, 603-608.

Barnhoorn, I.E.J., Bornman, M.S., Jansen van Rensburg, C., Bouwman, H., 2009. DDT residues in water, sediment, domestic and indigenous biota from a currently DDT-sprayed area. Chemosphere 77, 1236-1241.

Barnhoorn, I.E.J., van Dyk, J.C., Pieterse, G.M., Bornman, M.S., 2010. Intersex in feral indigenous freshwater Oreochromis mossambicus, from various parts in the Luvuvhu River, Limpopo Province, South Africa. Ecotox. Environ. Saf. 73, 15371542.

Bordet, F., Inthavong, D., Fremy, J., 2002. Interlaboratory study of a multiresidue gas chromatographic method for determination of organochlorine and pyrethroid pesticides and polychlorobiphenyls in milk, fish, eggs and beef fat. Int. J. AOAC 85 (6), 1398-1409.

Bornman, M.S., Van Vuren, J.H.J., Bouwman, H., De Jager, C., Genthe, B., Barnhoorn, I.E.J., 2007. Endocrine Disruptive Activity and the Potential Health Risk in an Urban Nature Reserve. WRC report No. 1505/1/07. Water Research Commission, Pretoria, South Africa.

Bouwman, H., 2004. South Africa and the Stockholm convention on persistent organic pollutants. SA. J. Sci. 100, 323-328.

Bouwman, H., Polder, A., Venter, B., Skaare, J.U.S., 2008. Organochlorine contaminants in cormorant, darter, egret, and ibis eggs from South Africa. Chemosphere 71, 227-241.

Chan, H.M., Trifonopoulos, M., Ing, A., Receveur, O., Johnson, E., 1999. Consumption of freshwater fish in Kahnawake: risks and benefits. Environ. Res. 80, 213-222.

Christoforidis, A., Stamatis, N., Schmieder, K., Tsachalidis, E., 2008. Organochlorine and mercury contamination in fish tissues from the river Nestos, Greece. Chemosphere 70, 694-702.

Cohn, B.A., Wolff, M.S., Cirillo, P.M., Sholtz, R.I., 2007. DDT and breast cancer in young women: new data on the significance of age at exposure. Environ. Health Perspect. 115, 1406-1414.
Cooper, G.S., Martin, S.A., Longnecker, M.P., Sandler, D.P., Germolec, D.R., 2004. Associations between plasma DDE levels and immunologic measures in AfricanAmerican farmers in North Carolina. Environ. Health Perspect. 112, 1080-1084.

Cox, S., Niskar, A.S., Narayan, K.M., Marcus, M., 2007. Prevalence of self-reported diabetes and exposure to organochlorine pesticides among Mexican Americans: Hispanic health and nutrition examination survey 1982-1984. Environ. Health Perspect. 115, 1747-1752.

Darko, G., Akoto, O., Oppong, C., 2008. Persistent organochlorine pesticide residues in fish, sediments and water from Lake Bosomtwi, Ghana. Chemosphere 72, 2124.

Du Preez, H.H., Heath, R.G.M., Sandham, L.A., Genthe, B., 2003. Methodology for the assessment of human health risks associated with the consumption of chemical contaminated freshwater fish in South Africa. Water SA 29 (1), 69-90.

DWA, 2012. Fish Health and Edibility of Two Freshwater Fish Species in Selected Dams in the North West Province. Prepared by the University of Johannesburg on behalf of ECO Dynamics for the Department of Water Affairs and Forestry and Rand Water. http://www.harties.org.za/hartiesdev/documents/ ProgressReport/FishEdibilityProgressReportNov2012.pdf.

EFSA, 2005. Opinion on the scientific panel on contaminants in the food chain on a request from the European Parliament related to the safety assessment of wild and farmed fish, Adopted on 22 June 2005. EFSA Journal 236, 1-118. Eskenazi,

B., Marks, A.R., Bradman, A., Fenster, L., Johnson, C., Barr, D.B., Jewel, N.P., 2006. In utero exposure to dichlorodiphenyltrichloroethane (DDT) and dichlorodiphenyldichloroethylene (DDE) and neurodevelopment among young Mexican American children. Paediatrics 118, 233-241.

Jiang, Q.T., Lee, T.K.M., Chen, K., Wong, H.L., Zheng, J.S., Giesy, J.P., Lo, K.K.W., Yamashita, N., Lam, P.K.S., 2005. Human health risk assessment of organochlorines associated with fish consumption in a coastal city in China. Environ. Pollut. 136, 155-165.

Jobling, S., Nolan, M., Tyler, C.R., Brighty, G., Sumpter, J.P., 1998. Widespread sexual disruption in wild fish. Environ. Sci. Technol. 32, 2498-2506.

Johnson, A., Friese, M., 2013. An Assessment of the Chlorinated Pesticide Background in Washington State Freshwater Fish and Implications for 303(d) Listings. Publication No. 13-03-007, Washington State Department of Ecology. <https://fortress.wa.gov/ecy/publications/SummaryPages/1303007.html>.

Jorgenson, J.L., 2001. Aldrin and Dieldrin: a review of research on their production, environmental deposition and fate, bioaccumulation, toxicology, and epidemiology in the United States. Environ. Health Perspect. 109 (suppl 1), 113-139.

Kalyoncu, L., Agca, I., Aktumsek, A., 2009. Some organochlorine pesticide residues in fish species in Konya, Turkey. Chemosphere 74, 885-889.

Kelce, W., Stone, C., Laws, S., et al., 1995. Persistent DDT metabolite p, p'-DDE is a potent androgen receptor antagonist. Nature 375, 581-585.

Klotz, D.M., Beckman, B.S., Hill, S.M., McLachlan, J.A., Walters, M.R., Arnold, S.F. 1996. Identification of environmental chemicals with estrogenic activity using a combination of in vitro assays. Environ. Health Perspect. 104 (10), 1084-1089.

Kojima, H., Katsura, E., Takeuchi, S., Niiyama, K., Kobayashi, K., 2004. Screening for estrogen and androgen receptor activities in 200 pesticides by in vitro reporter gene assays using Chinese hamster ovary cells. Environ. Health Perspect. 112 (5), 524-531.

Kramer, V.J., Giesy, J.P., 1999. Specific binding of hydroxylated polychlorinated biphenyl metabolites and other substances to bovine calf uterine estrogen receptor: structure-binding relationships. Sci. Tot. Environ. 233 (1-3), 141-161.

Marchand, M.J., Pieterse, G.M., Barnhoorn, I.E.J., 2010. Sperm motility and testicular histology as reproductive indicators of fish health of two feral fish species from a currently DDT sprayed area, South Africa. J. Appl. Ichthyol. 26, 707-714.

Marchand, M.J., van Dyk, J.C., Barnhoorn, I.E.J., Wagenaar, G.M., 2012. Histopathological changes in two potential indicator fish species from a hypereutrophic freshwater ecosystem in South Africa: a baseline study. Afr. J. Aquat Sci. 37 (1), 39-48.

McGlynn, K.A., Quraishi, S.M., Graubard, B.I., Weber, J.P., Rubertone, M.V., Erickson, R.L., 2008. Polychlorinated biphenyls and risk of testicular germ cell tumors. J. Natl. Cancer Inst. 100, 663-671.

Osibona, A.O., Kusemiju, K., Akande, G.R., 2006. Proximate composition and fatty acids profile of the African Catfish Clarias gariepinus. Acta SATECH 3, 85-89.

Park, D., Hempleman, S.C., Propper, C.R., 2001. Endosulfan exposure disrupts pheromonal systems in the Red-spotted newt: a mechanism for subtle effects of environmental chemicals. Environ. Health Perspect. 109, 669-673.

Pieterse, G.M., Marchand, M.J., van Dyk, J.C., Barnhoorn, I.E.J., 2010. Histological alterations in the testes and ovaries of the sharptooth catfish (Clarias gariepinus) from an urban nature reserve in South Africa. J. Appl. Ichthyol. 26, 789-793.

Rignell-Hydbom, A., Rylander, L., Hagmar, L., 2007. Exposure to persistent organochlorine pollutants and type 2 diabetes mellitus. Hum. Exp. Toxicol. $26,447-452$.

Sang, S., Petrovic, S., 1999. Endosulfan - A Review of its toxicity and its effects on the endocrine system. WWF (World Wild Life Fund - Canada). <http://www.wwf.ca/satellite/prip/resources/lindane.pdf>.

Sauviat, M.P., Pages, N., 2002. Cardiotoxicity of lindane, a gamma isomer of hexachlorocyclohexane. J. Soc. Biol. 196 (4), 339-348.

Storelli, M.M., 2008. Potential human health risks from metals ( $\mathrm{Hg}, \mathrm{Cd}$, and $\mathrm{Pb}$ ) and polychlorinated biphenyls (PCBs) via seafood consumption: estimation of target hazard quotients (THQs) and toxic equivalents (TEQs). Food Chem. Toxicol. 46 (8), 2782-2788.

Sunyer, J., Torrent, M., Munoz-Ortiz, L., Ribas-Fito, N., Carrizo, D., Grimalt, J., Antó, J.M., Cullinan, P., 2005. Prenatal dichlorodiphenyldichloroethylene (DDE) and asthma in children. Environ. Health Perspect. 113, 1787-1790. 
Szlinder-Richert, J., Barska, I., Mazerski, J., Usydus, Z., 2008. Organochlorine pesticides in fish from the southern Baltic Sea: levels, bioaccumulation, features and 940. temporal trends during the 1995-2006. Mar. Poll. Bull. 56, 927-

Urbach, J., 2007. Inconclusive Study on DDT Has Potentially Mortal Consequences. Human Health Policy. May 2007. <http://www.healthpolicyunit.org/scripts/ documents/> (accessed 11.09.12).

U.S. EPA., 1991. Office of Solid Waste and Emergency Response, Risk Assessment Guidance for Superfund. Volume I: Human Health Evaluation Manual, Supplemental Guidance: Standard Default Exposure Factors. Directive 9285.603; Interim Final. <http://www.epa.gov/oswer/riskassessment/pdf/OSWE Rdirective9285.6-03.pdf >.
U.S. EPA., 2011. Exposure Factors Handbook: 2011 Edition. National Center for Environmental Assessment, Washington, DC; EPA/600/R-09/052F. Available from the National Technical Information Service, Springfield, VA. http:// www.epa.gov/ncea/efh.

Van Ginkel, C.E., 2011. Eutrophication: present reality and future challenges for South Africa. Water SA 37 (5), 693-701.

Wang, D., Yu, Y., Zhang, X., Zhang, D., Zhang, S., Wu, M., 2013. Organochlorine pesticide in fish from Taihu Lake, China, and associated human health risk assessment. Ecotox. Environ. Saf. 98, 383-389.

Zhao, Y.G., Wan, H.T., Law, A.Y., Weu, X., Huang, Y.Q., Giesy, J.P., Wong, M.H., Wong, C.K., 2011. Risk assessment for human consumption of perfluorinated compound-contaminated freshwater and marine fish from Hong-Kong and Xiamen. Chemosphere 85 (2), 277-283. 